\title{
MACIEJ JABŁOŃSKI
}

Instytut Ekologii i Bioetyki, UKSW, Warszawa

\section{Public administration bodies competent in environmental protection in agriculture (requests and demands de lega lata and de lege ferenda)}

Key words: public administration, environmental protection, agriculture, European Union

Słowa kluczowe: administracja publiczna, ochrona środowiska, rolnictwo, Unia Europejska

Public administration is a basic vehicle that performs tasks at different levels of public authority (Izdebski 2007: 211). This also concerns the administration that is competent in making decisions concerning agriculture and rural development. Finding an organisational model and the functioning of a state administration, which would create a uniform system, is closely linked to the issue of sources of administrative law (Wrzosek 1986: 108). The Prime Minister defined the detailed scope of responsibilities of the Minister of Agriculture and Rural Development on the basis of Article 33 (1) and 1a of the Act of 8 August 1996 on the Council of Ministers (A: art 33 p. 1and 1a). The second paragraph provides that the Minister of Agriculture and Rural Development heads the following areas of government administration:

1) agriculture;

2) rural development;

3) agricultural markets;

4) and administers parts 32, 33 and 35 of the state budget (B: art 32, 33 and 35). 
The Minister responsible for Rural Development serves as the managing authority referred to in Article 74 (2) of Regulation No. $1698 / 2005$ and, in addition, carries out a number of tasks specified in the Act on support for rural development.

The Minister responsible for public finance, in turn, performs the tasks associated with the mobilisation of funds from the EAFRD determined for a Member State and for a competent authority under the provisions of Regulation No. 1290/2005 and Regulation No. 885/2006, including granting accreditations as a paying agency. By the Regulation of the Council of Ministers of 3 November 1999 on the establishment of the Ministry of Finance, pursuant to Article 39 (1) of the Act of 8 August 1996 on organization and operation of the Council of Ministers and the scope of activities of ministers, the Ministry of Finance was established (C: $\operatorname{art} 39$ p. 1). The Minister of Finance directs the following areas of government administration:

1) the budget;

2) public finance;

3) financial institutions.

On the basis of the Act on mobilising funds from the Guarantee Section of the European Agricultural Guidance and Guarantee Fund, the Minister of Finance establishes the paying agency and submits to the Commission information and documents concerning the establishment of the paying agency and any changes in this area. The Minister of Finance may grant for a fixed period of time a conditional accreditation referred to in Article 3 (1) of the Act, submitting to the Commission information and documents relating to the conditional establishment of the paying agency and any changes in this respect, and also monitors whether paying agencies meet the accreditation criteria. The Minister of Finance, by regulation, may revoke accreditation if the paying agency does not meet the required criteria for accreditation and does not introduce, within a prescribed period, changes which should be introduced in order to meet all the accreditation criteria. If the European Commission finds irregularities in spending means from the Fund by the paying agencies, the Minister sends to the Commission information on measures taken to ensure compliance of 
spending means from the Fund with the principles of the European Union.

On the basis of the Act on mobilising funds from the EU budget allocated to the Common Agricultural Policy, the Minister of Finance has identical powers of granting and revoking accreditation and of exercising permanent supervision over paying agencies.

Local governments and the Voivodship Marshal participate in the implementation of the RDP as regards performing the tasks of the managing authority, i.e. the implementation of measures under the program, delegated to local governments under the Act on support for rural development. In accordance with its Article 14 (1) (D: art 14 p. 1), the local government carries out the tasks on the local scale, especially as concerns the modernization of rural areas. The Act on support for rural development with the participation of the European Agricultural Fund for Rural Development provides that the program is implemented in the territory of Poland and includes activities embracing the scope of powers of local government. Article 6 (1) of the Act provides that the tasks of managing authority in implementing the activities under the program, including the granting of aid, are performed, as tasks delegated in accordance with Article 75 (2) (E: art 75 p. 2) of Regulation No. 1698/2005, by, inter alia: the local government - in the case of activities referred to in Article 5 (1) p. 6, i.e.: improving and developing infrastructure related to the development and adaptation of agriculture and forestry through land consolidation and management of agricultural water resources. The Act also indicates other government tasks pertaining to the region:

1) basic services for economy and rural population;

2) countryside renewal and development;

3) implementation of local development strategies;

4) implementation of cooperation projects;

5) running the local action group.

Voivodship governments will be responsible for the process of call for and verification of proposals, as well as the supervision of projects implemented by the Local Action Groups (LAG), in the areas where the LAGs are established. The legal procedure for evaluating proposals is 
as follows: a proposal with the attached local development strategy is subject to substantive and formal evaluation, and next the Voivodship executive board adopts a resolution on signing an agreement on the conditions and manner of implementing the local development strategy with the selected LAGs.

Both in the past and in the present programming period, Poland relies, in implementing the objectives of the RDP, on the measures proposed by the European Commission, and their topical scope is undoubtedly very wide, which in turn raises a question whether we should not ask if there are areas specific of Poland and the new member states, which would require special treatment, and thus specially designed activities (F: p. 14). Thereby, practically under the two perspectives funded, due to the short period of the formal EU membership Poland participated as a performer of earlier assumptions. Of course, unfavourable arrangements should not be assumed $a$ priori, but by drawing upon already gained experience, our country should, during the next programming period, actively participate in developing rules for financing the development of agriculture and rural areas within the EU. The future Common Agricultural Policy should retain its Community nature, and further changes which result from internal and external conditions should not lead to questioning the basic principles of the CAP, including the market unity, the Community preference principle, the principle of uniformity of instruments and the principle of financial solidarity. This should certainly refer to the issues, which are taken up both dedicated bodies of the EU and individual Member States (G: p. 26). Even now, participation in the decision-making process in agricultural policy of the European Union requires a reasonable association of nationwide state interests with multiple group interests because state policies are an effect of, on the one hand, a certain development project of the country, preferred by the ruling and business elites, and, on the other hand, of efforts related to sectoral interests (Styczeń 1997: 317).

The primary and strategic objective of Polish foreign policy in recent years has been our quick accession to the European Union. Therefore, many areas of functioning of the state and economy must be organized and managed in accordance with the priorities of our membership in 
the EU (Rudnicki 2005: 99). This desired state of affairs will be possible when the actions undertaken are based on obvious legal prerequisites. It will be possible if the legal basis is clear and unambiguous, since the high quality of the legal environment has been recognized as one of the key elements to improve the competitiveness of the EU economy in the Lisbon Strategy. The general feeling is that the simplification and improvement of Community law will facilitate its implementation by the member states and reduce the costs borne by both companies and the administration. The implementation of this policy is supported by the Better Regulation initiative, whose main aim is to improve the legal environment by reviewing and eliminating unnecessary regulations, simplifying procedures, assessing the impact of legislation, reduction of administrative burdens. The significance of the concept of Better Regulation is also emphasized by Interinstitutional Common Approach to Impact Assessment agreed in November 2005, which shows the basic principle that each institution is responsible for estimating the effects of its own legislative proposals and modifications introduced to a draft legal act. The exchange of experiences and best practices will make it possible to improve the implementation of regulatory reform in Poland. At the same time, it will create an opportunity for better recognition Poland's position at the Community level, which will allow the targeting of Better Regulation policy in line with Polish priorities. In 2008, for the first time, the Presidency is held by a new Member State - Slovenia. This offers an opportunity to continue the process of Better Regulation focusing to a greater extent on the specificity of new Member States. In order for the above objectives to be achieved, it is necessary to keep trying to meet the prerequisites in the form of analysing and diagnosing the situation of the Community. Only then will not only an economic or political union become a fact but also not just an economic union or political, but also the provisions of legal norms of Community law will be implemented (Jabłoński 2002: 173). The Member States should be encouraged to use the instruments of rural development, since it is the second pillar, which allows the best adjustment of solutions to specific needs. The risk associated with the market or the weather is different in different member states, sectors, and even depending on a region 
or a sector in a member state. Therefore it is better to allow the member states, regions or groups of manufacturers to assess on their own, within the resources available in the second pillar, the risk they are facing and to decide which solution would be the best for them (H: Brussels COM (2007) 722 final).

The Common Agricultural Policy is subject to assessment and criticism. More and more emphasis is placed on rural development and less and less on direct support for production. The key to the further development of agriculture and rural areas is versatility. Poland should define its strategic issues in both areas, be prepared for their presentation and its active defence. At the same time, farmers need to be informed of possible changes so that they can prepare for them early and effectively enough (I: p. 5). The creation of the EAFRD and of one set of rules for funding and programming significantly simplified the policy of financing rural areas, however, the alarming fact is that in real terms the 2007-2013 budget earmarked for this purpose has been severely limited (although nominally EAFRD has greater financial resources than the second pillar of the Guarantee Section and Guidance Section in total) (J: p. 82-83).

In the years 2007-2013, Poland is the biggest beneficiary of rural development programs in the EU. However, this situation may change in the next financial period, by reducing transfers to Poland and moving them to Bulgaria and Romania. In this case, additional amounts derived from modulation could finance a pool of funds earmarked for the development of agriculture and rural areas. Modulation in this case would be an instrument to shift funds from Pillar I to Pillar II at the expense of the group of medium and large farms. Thus, a very important aspect in formulating the Polish position on the modulation will be the amount of funds received by Poland under the future RDP. For Poland, support for rural development is extremely important, because of the huge investment needs in Polish agriculture and the necessity of ensuring broad support for agriculture and rural areas, amongst other reasons. The instruments of rural development support should offer opportunities of development and catching-up with agriculture in the EU-15. The method of allocating resources to the second pillar of the CAP should take 
into account the development needs of the new member states while increasing the coherence of the EU, so that challenges in the face of external competition can be coped with jointly and independently. It is necessary to develop such an algorithm for the allocation of funds to the second pillar of the CAP which will take into account the development needs of rural areas in regions with a worse economic situation. It is important to bear in mind that leaving these areas without adequate support and development exacerbates disparities across the EU. Funds for rural development, in addition to cohesion policy, should help make up for these differences in an efficient way and contribute to the dynamic development of the whole Community. In 2008, the first results were expected of enhanced efforts to implement the Lisbon strategy at the regional level with the new European cohesion policy and rural development policies which were adopted by all Member States in 2007 (K: p. 6).

\section{Bibliography}

Izdebski H., 2007, Foundations of modern states, Warsaw.

Jabłoński M., 2002, Social Policy of the European Union, [in:] Poland in the "old" and "new economy". Look A macro-, mezzo-, and micro-economic view, III PhD Conference, Szczecin, p. 173.

Rudnicki M., 2005, Legal and financial aspects of the public tasks of local government units related to environmental protection, Lublin.

Styczeń B., 1999, Decision-making process in the area of the Common Agricultural Policy - lessons for Poland, [in:] European integration. Implications for Poland, collective work edited by Jacek Czaputowicz, Kraków, p. 317.

Wrzosek S., 1986, The concept of unity in the organization and functioning of state administration, doctoral dissertation, Warsaw.

(A) Jour. of Laws of 2003., No. 24, item 199 as amended.

(B) The objective scope established by the regulation of the Minister of Finance dated 5 May 2006 on the classification of parts of the budget and determination of their administrators (Jour. of Laws of 11 May 2006). The cited regulation was passed pursuant to Article 104 (2) of the Act of 30 June 2005 on public finance (Jour. of Laws No. 249, item 2104 and No. 169, item 1420 and of 2006 No. 45, item 319).

(C) Jour. of Laws of 1999., No. 91, item $1020^{\text {th }}$.

(D) Provincial self-government Act of 5 June 1998 (Jour. of Laws of 1998., No. 91, item 576). 
(E) Article 75 (2): When part of its tasks are delegated to another entity, the Managing Authority shall retain full responsibility for the efficiency and correctness of managing the performance of these tasks.

(F) Directions of Reform of the Common Agricultural Policy in the review scheduled for 2008/2009 from the perspective of Poland, Warsaw 2006, p. 14.

(G) The Polish vision of the Common Agricultural Policy against the challenges of evaluation of its functioning, the Ministry of Agriculture and Rural Development, Warsaw 2007, p. 26.

(H) The Communication from the Commission to the Council and European Parliament Preparing for the CAP reform. Brussels 20 November 2007 COM (2007) 722 final.

(I) Conclusions for Poland based on The report of the informal meeting of the Council for. Agriculture and Fisheries, 20-22 May 2007, Brussels 25 June 2007, p. 5.

(J) The CAP. Modern rural development policy, Warsaw 2007, p. 82-83.

(K) Communication from the Commission to the European Parliament, the Council, the European Economic and Social Committee and the Committee of the Regions, Annual Policy Strategy for 2008, Brussels, 21 February 2007, p. 6.

\section{Organy administracji publicznej kompetentne w zakresie ochrony środowiska $w$ rolnictwie (wnioski i zalecenia de lege lata i de lege ferenda)}

\section{STRESZCZENIE}

Podejmowanie działalności w rolnictwie wiąże się z realizacja standardów ochrony środowiska. Dotyczy to polskiej administracji publicznej oraz organów Unii Europejskiej. Spójna polityka w zakresie rozwoju rolnictwa umożliwi finansowanie ochrony środowiska w tej dziedzinie zarówno w ramach bieżącego budżetu, jak również w ramach perspektywy finansowej 2014-2020.

\section{SUMMARY}

Undertaking activities in agriculture associated with the implementation of environmental standards. This applies to Polish public administration and European Union bodies. A coherent policy for agricultural development will enable the financing of environmental protection in this area, both within the current budget, as well as the financial period 2014-2020. 